\title{
特集 染色加工における環境対応最前線（その1）
}

\section{エコマーク事業における繊維製品 の認定基準見直しについて}

佐野裕隆

\section{はじめに}

(財)日本環境協会では, 環境保全型商品にエコマーク (図 1）を付ける任意のマーク制度として，1989年（平成元 年）からエコマーク事業を実施している.

当事業は, 環境保全に役立つと認められる商品に「エ コマーク」を付けることにより，商品の環境的側面に関 する情報を広く社会に提供し，環境にやさしくありたい と願う消費者による商品選択の促進を目的としている.

対象は, 消費者に推奨することが環境保全のために適 切と判断されたものであり，基本的に次の要件に該当す る商品である.

(1)その商品の製造, 使用, 廃棄などによる環境への負 荷が, 他の同様の商品と比較して相対的に少ないこ と

(2)その商品を利用することにより，他の原因から生ず る環境への負荷を低減することができるなど環境保 全に寄与する効果が大きいこと

こうした取り組みにおいて注意するべき点は，事業目 的が環境保全に役立つ商品の「選択を推奨する」もので あり，エコマークが付いているからといって商品を無駄 に使ったり，その効果を過大に評価して利用するのでは， 必ずしも「環境への配慮」にはならないことである。

また，当事業は，制度として商品の規格や標準を定め ようとするものではなく, 商品の品質や安全性といった 直接的な消費者の利益を保護することを目的とするもの でもない.

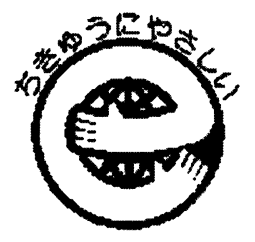

図 1 エコマーク
以上の事業主旨に基づき展開しているエコマーク認定 商品は, 2002年 9 月末現在で64分野, 5308商品, 1826社 である。

\section{エコマーク事業の概要}

当事業の基本スキームは，ISO 14020および ISO 14024 の環境ラベルに関する規格に基づいて運営を行ってお り，エコマークはタイプI環境ラベルと分類されてい る. ISO 14020および ISO 14024は, 制度実施に当たって の透明性と信頼性を確保しょうとするものであり, 主と して環境ラベル制度を実施・運営する機関が遵守するべ き項目を定めている.

タイプIの環境ラベル制度は,「特定の商品類型（カ テゴリー）を定めて, 商品のライフサイクル全体を考慮 してあらかじめ定められた多様な認定基準に基づき, 商 品への環境優位性を示すラベルの使用を認証する, 第三 者による自主的な制度」とされている。

現在, エコマークと同様なタイプIの環境ラベル制度 は, ドイッ, 北欧, EU, アメリカ, カナダ, 中国, 韓 国，台湾など世界のおよそ30か国・地域で実施されてお り, 今後も増加すると考えられる。

\section{エコマーク商品認定・使用申込}

繊維製品にエコマークを使用するためには, 当該商品 のエコマーク商品認定を受ける必要があり, 申し込みに 基づいて事前に審査を行う. 申込手続きは, 図 2 に示す とおり所定の「エコマーク商品認定・使用申込書」とと もに該当する認定基準に則った証明書を添付し，エコ マーク事務局に提出する. 申し込みがあった商品につい てエコマーク審査委員会での商品認定審査を経て, 認定 となった商品はエコマーク使用契約を当協会と締結し, 当該商品へのエコマーク表示を行うこととなる.

審査期間は申し込みから約 2 か月, 審査料は無料とし 


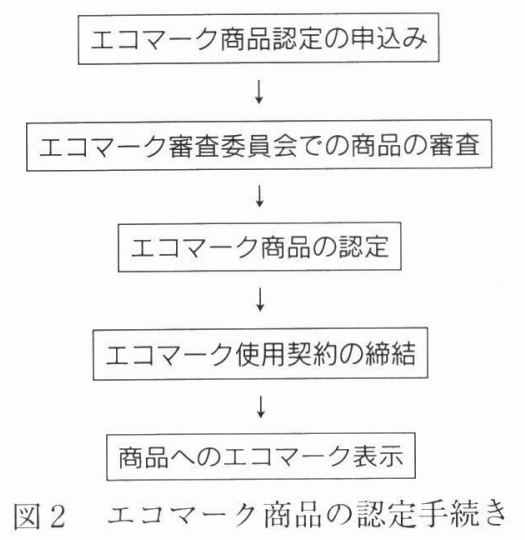

ているが, 認定となった商品は所定のエコマーク使用料 を支払うこととなる．また，審査のための第三者機関の 試験などに要する費用は申込者の負担となる。

\section{エコマーク商品認定基準}

商品認定審査を行うに当たっては, 先行して商品類型 と呼ばれる商品分野の設定と認定基準があることが前提 となる。繊維製品は, エコマーク商品類型 No. 21「乳幼 児用布製书むつ」, No. 44「無漂白の衣服, 寝具, 夕オ ル」, No. 48「布製ショッピングバッグ」, No. 51「未利 用繊維を使用した繊維製品」, No. 103 「再生 PET樹脂を 使用した衣服」，No. 104「再生 PET 樹脂を使用した家庭 用繊維製品」扔よびN No. 105「再生 PET 樹脂を使用した 工業用繊維製品」という商品類型を1990～1999年にかけ て設定しており，すでに個別のエコマーク商品認定・使 用申迟を受け付けている状況である。

認定基準は，1996年にISO 14024に基づく商品ライフ サイクルの概念を導入し，エコマーク事業実施要領に規 定する商品ライフステージ環境負荷項目選定表をもとに 策定される。また，ISO 14024に基づく運営方法として， 認定基準は 5 年以内ごとに見直されることとなり, 商品 類型 No が100番台の認定基準策定時にはこの商品ライ フステージ環境負荷項目選定表をもとに検討が行われ る。1997年策定の「再生 PET 樹脂を使用した衣服」，「再 生 PET 樹脂を使用した家庭用繊維製品」㧍よび「再生 PET 樹脂を使用した工業用纎維製品」を検討した際にも, 本手法により環境負荷の総合的検討が行われた。

今回, 「再生 PET 樹脂を使用した衣服」,「再生 PET 樹 脂を使用した家庭用瀻維製品」および「再生 PET 樹脂 を使用した工業用瀻維製品」は，その策定から 5 年が経 過することから上述の有効期限に基づく見直し作業を行 い，エコマーク商品類型No. 21 「乳幼児用布製掞むつ」, No. 44「無漂白の衣服, 寝具, 夕オル」, No.48「布製 ショッピングバック」挍よ゙゙No. 51「未利用瀻維を使用 した繊維製品」の商品ライフサイクルの概念導入に基づ く検討と併せて「衣服」，「家庭用瀻維製品」および「工 業用㵶維製品」として整理統合した。本認定基準につい
ては2002年11月末現在, 認定基準(案)として公表の可否 を審議するための準備を進めている段階である，今後の 予定は，2002年12月から2003年 2 月まで認定基準(案)の 公表による意見の受付を行い，一般からの意見をもとに 認定基準(案)の再検討，修正を行う手続きを経て，2003 年 4 月を目標に認定基準として制定することとしてい る.

図 3 に「衣服」の商品ライフステージ環境負荷項目選 定表を示す。

\section{繊維製品の認定基準}

繊維製品は，様々な観点から環境負荷低減に取り組ま れて㧍り，近年は再生 PET 樹脂の使用が増加している. 今回の見直し作業では, 反毛繊維㧍よび未利用纎維の利 用促進を図るため, 個別に設定されていた商品類型を「衣 服」,「家庭用繊維製品」および「工業用繊維製品」とし て統合した。衣服は, 経済産業省資料によると, 年間 110 万 9 千 $\mathrm{t}$ が消費されており，再生資源として約 18 万 $\mathrm{t}$ が 回収されている．近年の衣服の低価格化，供給量・排出 量の増加により, 故瀻維事業者の回収寸る使用済及瀻維 製品の量が増加しており, 反毛などの需要頭打ちなどか ら本来リサイクルできる㵶維製品がリサイクル不能品と して廃棄される例が増加傾向にある。これらの問題に対 し, 纎維業界では使用済み衣服の引き取り・リサイクル を進めており，本商品類型は，これまでの未利用繊維ま たは再生 PET 樹脂を使用した衣服に, 新たにリサイク ル瀻維などの使用や引き取り・リサイクルシステムの整 備を認定基準として採り入れ，瀻維から瀻維へのリサイ クルに力点を置いた. 具体的なエコマークの役割として, エコマークを付けることによってリサイクル商品の普及 を図り，いわゆる循環の輪の出口部分のパイプを太くす ることに重点を置くこととした。

化学物質の使用については, これまでの認定基準内容 を大幅に強化し, 化学物質污染の軽減に一層努めるもの

\begin{tabular}{|c|c|c|c|c|c|c|}
\hline \multirow[b]{2}{*}{ 環境負荷項目 } & \multicolumn{6}{|c|}{ 商品のライフステージ } \\
\hline & $\begin{array}{l}\text { A. } \\
\text { 資源採取 } \\
\end{array}$ & $\begin{array}{l}\text { B. } \\
\text { 製造 } \\
\end{array}$ & $\begin{array}{l}\text { C. } \\
\text { 流通 }\end{array}$ & $\begin{array}{l}\text { D. } \\
\text { 使用消費 }\end{array}$ & \begin{tabular}{|l|} 
E. \\
廃棄
\end{tabular} & $\begin{array}{l}\text { F. } \\
\text { リサイタル }\end{array}$ \\
\hline 1. 資源の消費 & () & 0 & (C) & (2) & (0) & \\
\hline 2. 地球温暖化影響物質の排出 & & 0 & & 0 & & \\
\hline 3.オゾン層破壞物質の排出 & & & & 0 & (2) & \\
\hline 4. 生態系への影響 & & & & & & \\
\hline 5. 大気污染物質の排出 & & (O) & & & & \\
\hline 6. 水質污濁物質の排出 & & (C) & & 0 & & \\
\hline 7. 廃裹物の発生. 处理処分 & & 0 & & 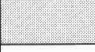 & & () \\
\hline 8. 有害物質などの使用・排出 & 0 & (C) & & (C) & & \\
\hline 9. その他の環境負荷 & 0 & (C) & & & & \\
\hline
\end{tabular}

図 3 衣服に関する商品ライフステージ環境負荷項目選 定表 
とした。化学物質は，その影響力を検討し，法などの遵 守, 使用の禁止, 数值基準の設定, 定性的基準の設定, 報告という段階的な認定基準設定の考え方を図 4 に示す とおりエコマーク類型・基準制定委員会に関するガイド ラインで定めている.

このうち図 4 ステップ 3 に示す報告レベルの認定基準 は，指定した物質に関する商品への使用有無などの情報 をエコマーク事務局へ報告するものとして位置づけてき
た。今回新たな考え方として，この報告レベルの物質の 扱いについて，その使用を製造事業者またはアパレル側 からエコマーク事務局への報告として認定基準化するの ではなく，報告義務はないが健康，環境への影響が懸念 される物質として, 文献, 研究事例などに被害事例など がある物質などについて表 1 のとおり情報提供すること とした。この情報提供によって，製造事業者またはアパ レル各社はエコマーク商品に該当物質を使用することは

1. 化学物質

エコマーク認定基準案策定にあたっては, 商品のライフステージに関連する化学物質のうち, 検討対象として挙げら れた化学物質について, 以下の考え方に基づいて検討を行うこととする.

\begin{tabular}{|c|c|}
\hline \multicolumn{2}{|l|}{ 検討対象の化学物質群 } \\
\hline \multicolumn{2}{|l|}{ A. 国内法規などに基づく規制の有無 } \\
\hline A-1. 対象商品分野に関する法規など & あり/なし \\
\hline A-2. 対象商品分野以外の法規など & あり/なし \\
\hline \multicolumn{2}{|l|}{ マなし } \\
\hline \multicolumn{2}{|l|}{ B . 条約, 海外法規などに基づく規制の有無 } \\
\hline B-1. 対象商品分野に関する法規など & ありノなし \\
\hline B-2. 対象商品分野以外の法規など & あり/なし \\
\hline \multicolumn{2}{|l|}{ マなし } \\
\hline \multicolumn{2}{|l|}{ C. 海外エコラベル, 業界などの自主規制や任意規格の有無 } \\
\hline C-1. 対象商品分野に関する海外エコラベル基準など & あり（国内・海外）／なし \\
\hline C-2. 対象商品分野以外の海外エコラベル基準など & あり (国内・海外) /なし \\
\hline \multicolumn{2}{|l|}{ マなし } \\
\hline \multirow{2}{*}{$\begin{array}{l}\text { D. 法規などで規制対象とされていない物質のうち, 環境破壊の疑 } \\
\text { いが高く，エコマークとて取り上げる意義の高い物質 }\end{array}$} & \multirow{2}{*}{$\begin{array}{l}\text { 物質名： } \\
\text { 根 拠：(研究報告等) }\end{array}$} \\
\hline & \\
\hline \multicolumn{2}{|l|}{$\begin{array}{c}\nabla \text { なし } \\
\text { 基準化しない }\end{array}$} \\
\hline
\end{tabular}

ステップ2. 基準化の検討 2

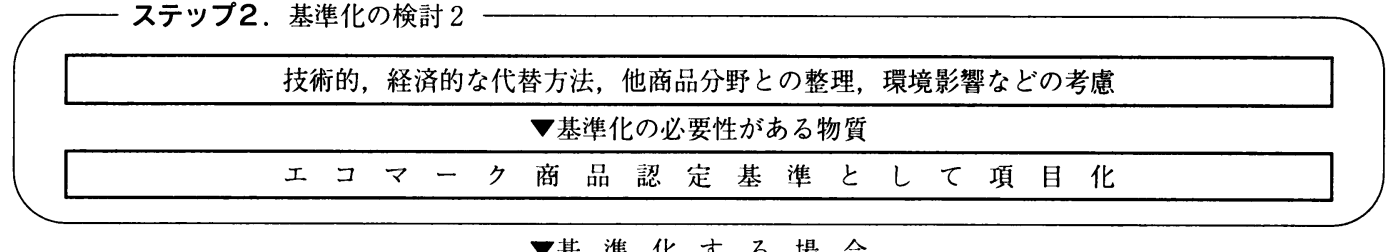

ステップ3. 基準化の方法

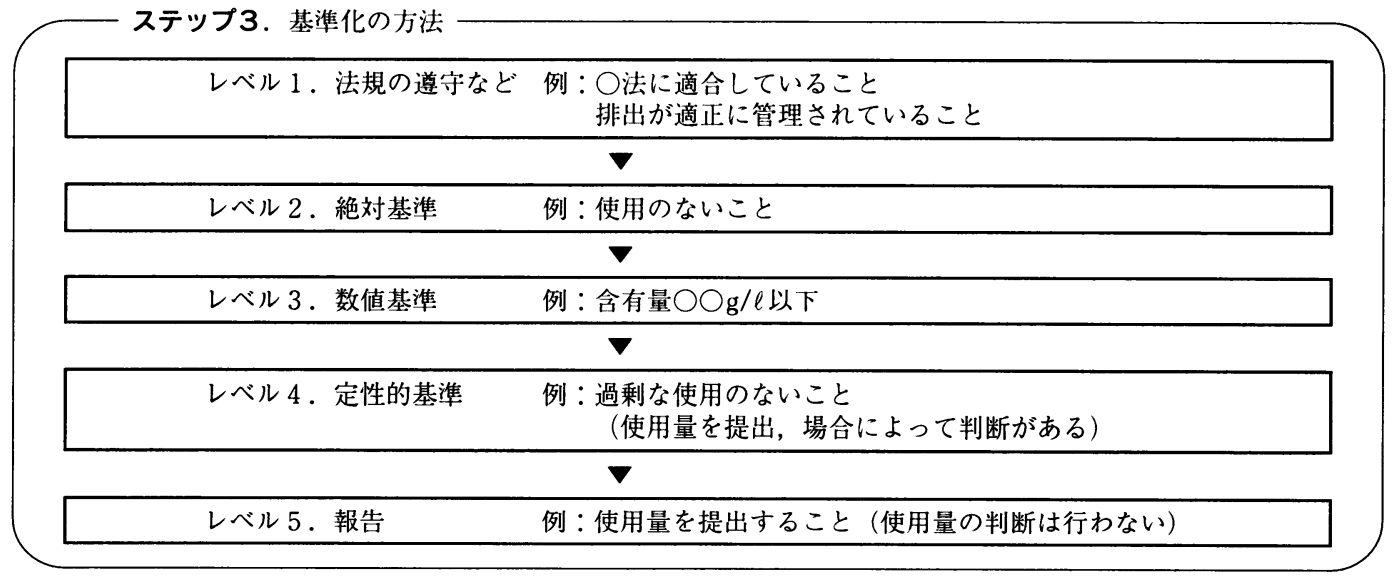

図 4 化学物質に関する環境負荷項目の考え方の整理 


\section{表 1 情報提供物質リスト}

DISPERSE YELLOW 64

DISPERSE RED 15

DISPERSE RED 60

DISPERSE YELLOW 4

DISPERSE YELLOW 54

SOLVENT YELLOW 1

DISPERSE BLACK 1

DISPERSE BLACK 2

DISPERSE BLACK 3

ACID RED 27

ACID RED 85

ACID RED 115

ACID RED 151

ACID YELLOW 23 (FD\&C YELLOW No. 5 TARTRAZINE)

ACID YELLOW 36

ACID VIOLET 17

VAT RED 1

VAT ORANGE 5

VAT GREEN 1

DISPERSE ORANGE 13

DISPERSE YELLOW 4

DISPERSE BLUE 27

DISPERSE BLUE 85

DISPERSE BLUE 153

DISOERSE BLACK 6

DISPERSE YELLOW 3 (SOLVENT YELLOW 77)

DISPERSE BROWN 1

DISPERSE BLACK 153

DISPERSE BLACK 6

SOLVENT RED 1

SOLVENT RED 26 (CI 26120)

ACID YELLOW 36 (METANIL YELLOW, CI 13065)

ACID BLACK 48

ACID RED 85 (CI 22245)

EOSINE

BASIC RED 46

BASIC RED 22 (SYNACRIL RED 3B LIQUID)

BLACK BASE 1

NEUTRICHROM RED

SUPRAMINE RED

DIAZOL ORANGE

SUPRAMINE YELLOW

BRILLIANT GREEN

TURQUOISE REACTIVE

REMAZOL SCHWARZ B

REMAZOL GOLD GELB RNL

LEVAFIX MARINBLAU E-2BA

LEVAFIX BLACK E-G, E-B

IRGALITE ORANGE F2G (PIGMENT ORANGE 34, Cl 21115)

D\&C YELLOW 11

QUINOLINE YELLOW

DISPERSE RED 60

DISPERSE ORANGE 11

DISPERSE YELLOW 13

DISPERSE BLUE 27

DISPERSE BLUE 56

DISPERSE BLUE 72

DISPERSE BLUE 113

DISPERSE VIOLET K

DISPERSE VIOLET 8

油溶性染料

SOLVENT ORANGE 60

SOLVENT RED 179

染

$$
\text { 料 }
$$

黄色染料分解生成物（塩素化ホスゲン化合物）

NAPHTHOL AS

NAPHTHOL AS-D

紫外線吸収剂

TINUVIN P

その他の繊維用処理剤の成分物質

四塩化炭素

ビスフェノールA 誘導体

フタール酸ジ-2-エチルヘキシル

アジピン酸ジ-2-エチルヘキシル

有機すず化合物
可能であるが, 将来の認定基準としての制限の可能性, 消費者への被害対策の可能性などのリスクを考慮するこ とになり，トータルバランスで商品への環境配慮を行う 必要が生じる，健康，環境への影響が懸念されるに留ま る物質であっても，このような手法により一層の環境配 慮が見込めるため，本項目は認定基準を策定する項目と して選定された。なお，本情報提供については，国立医 薬品食品衛生研究所との検討により, 認定基準のレベル, 情報提供物質の見直しを行うこととなる。

個別化学物質については，次のとおり整理した。

遊離ホルムアルデヒド量については,「有害物質を含 有する家庭用品の規制に関する法律」において繊維製品 への規制が乳幼児用一般衣料「検出しないこと」, 下着 類「75ppm 以下」とされている. 本商品類型では, シッ クハウス原因物質など健康被害をもたらす物質として遊 離ホルムアルデヒド量を乳幼児用一般衣料品については 法規で定められているレベルと同様に使用禁止, 直接肌 に触れるものではない外衣 $300 \mathrm{ppm}$ 以下，その他衣服 75 ppm 以下として認定基準を策定した。ここでは，その 他，衣服について「下着を除く直接肌に触れる可能性の 高い衣服を指す」こととした。「家庭用繊維製品」およ び「工業用瀻維製品」においては, 衣服と同様に乳幼児 用製品（おむつなど）を「検出しないこと」，直接肌に 触れる可能性の高い商品を「75ppm 以下」とした。 そ の他の商品は300ppm（屋外に設置される商品は, 遊離 ホルムアルデヒド量に関する認定基準を適用しない）と した。遊離ホルムアルデヒド量は商品の保管状況などに より変化するため, 製造事業者またはアパレル各社によ る出荷時以降の遊離ホルムアルデヒド量の正確な把握は 困難である。そのため, 証明方法は定量基準に一般的に 用いる「試験結果の提出」とし, 認定基準値は出荷時の 試験結果の值を用いることとした。試験実施者は特に問 わないが, 遊離ホルムアルデヒド量の試験は厚生省令34 号を採用した。試験機関により JIS L 1041を規定してい る場合もあるが, 内容的にはほほ同義であり, 本商品類 型は厚生省令34号と記載した。なお，文献によると形態 安定加工商品の一部に, 密封保管したところ遊離ホルム アルデヒド量が75ppm を越える值が検出された例があ り, 樹脂の経時的な加水分解などが原因であると考えら れたことから, 出荷後の流通段階や使用・消費段階にお いても風通しのよい場所で保管するなどの注意が望まれ る.

染料については，染料および有機顔料製造会社生態学 毒物学協会（ETAD）が製造・販売を自主規制している 染料群リストとして表 2 のとおり(1)分解して発ガン性ア ミン類を生成する可能性があるアゾ系染料，(2)発ガン性 染料, (3)皮虐感作性染料を元に, EU Directive76/769/EEC により規制される染料およびECOTEXに規定される染 
表 2 染料リスト

(1)分解して下記の発癌性アミン類を生成する可能性があるアゾ 系染料

\begin{tabular}{|c|c|c|}
\hline \multicolumn{3}{|c|}{ 発癌性ランク (A1) } \\
\hline $92-67-1$ & \multicolumn{2}{|l|}{ 4-aminobiphenyl } \\
\hline $92-87-5$ & \multicolumn{2}{|l|}{ Benzedrine } \\
\hline $95-69-2$ & \multicolumn{2}{|l|}{ 4-chloro-o-toluidine } \\
\hline $91-59-8$ & \\
\hline \multirow{2}{*}{\multicolumn{2}{|c|}{ 発癌性ランク（A2） }} & \\
\hline & & \\
\hline $99-55-8$ & \multicolumn{2}{|l|}{ 2-amino-4-nitrotoluene } \\
\hline $106-47-8$ & \multicolumn{2}{|l|}{ 4-chloroaniline } \\
\hline $615-05-4$ & \multicolumn{2}{|l|}{ 2, 4-diaminoanisole } \\
\hline $101-77-9$ & \multicolumn{2}{|c|}{ 4, 4'-diaminodiphenylmethane } \\
\hline $91-94-1$ & \multirow{2}{*}{\multicolumn{2}{|c|}{$\begin{array}{l}3,3 \text {-dichlorbenzidine } \\
\text { o-dianisidine: } 3,3 \text {-Dimethoxybenzidine }\end{array}$}} \\
\hline $119-90-4$ & & \\
\hline $119-93-7$ & \multicolumn{2}{|c|}{ o-tolidine; 3, 3'-Dimethylbenzidine } \\
\hline $838-88-0$ & \multicolumn{2}{|c|}{ 4, 4'-diamino-3, 3'-dimethyldiphenylmethane } \\
\hline $120-71-8$ & \multicolumn{2}{|l|}{$\mathrm{p}$-cresidine } \\
\hline $101-14-4$ & \multicolumn{2}{|c|}{ 4, 4'-diamino-3, 3'-dichlorodiphenylmethane } \\
\hline $101-80-4$ & \multicolumn{2}{|c|}{ 4, 4'-diaminodiphenylether } \\
\hline $139-65-1$ & \multicolumn{2}{|c|}{$4,4^{\prime}$-diaminodiphenylsulfide } \\
\hline $95-53-4$ & \multicolumn{2}{|l|}{$\mathrm{o}$-toluidine } \\
\hline $95-80-7$ & \multicolumn{2}{|l|}{ 2, 4-diaminotoluene } \\
\hline $137-17-7$ & \multicolumn{2}{|l|}{ 2, 4,5-trimethylaniline } \\
\hline $90-04-0$ & \multicolumn{2}{|l|}{$\mathrm{o}$-anisidine } \\
\hline $95-68-1$ & \multicolumn{2}{|l|}{ 2,4-xylidine } \\
\hline $87-62-7$ & \multicolumn{2}{|l|}{2,6 -xylidine } \\
\hline $60-90-3$ & \multicolumn{2}{|l|}{4 amino-azo-benzen } \\
\hline \multicolumn{3}{|c|}{ (2) 発癌性染料 } \\
\hline $569-61-9$ & C. I. BASIC RED 9 & $\mathrm{Cl} 42500$ \\
\hline $2475-45-8$ & C. I. DISPERSE BLUE 1 & $\mathrm{CI} 64500$ \\
\hline $3761-53-3$ & C. I. ACID RED 26 & CI 16150 \\
\hline $6459-94-5$ & C. I. ACID RED 114 & CI 23635 \\
\hline $2602-46-2$ & C. I. DIRECT BLUE 6 & \\
\hline $1937-37-7$ & C. I. DIRECT BLACK 38 & CI 30235 \\
\hline $573-58-0$ & C. I. DIRECT RED 28 & CI 22120 \\
\hline & C. I. DISPERSE YELLOW & CI 11855 \\
\hline
\end{tabular}

$$
\text { (3)皮膚感作性染料 }
$$

\begin{tabular}{|c|c|c|}
\hline $2475-46-9$ & C. I. DISPERSE BLUE 3 & $\mathrm{Cl} 61505$ \\
\hline & C. I. DISPERSE BLUE 35 & \\
\hline & C. I. DISPERSE BLUE 106 & \\
\hline & C. I. DISPERSE BLUE 124 & \\
\hline $2832-40-8$ & C. I. DISPERSE YELLOW 3 & CI 11855 \\
\hline $730-40-5$ & C. I. DISPERSE ORANGE 3 & Cl 11005 \\
\hline & C. I. DISPERSE ORANGE 37 & \\
\hline \begin{tabular}{|l|}
$2872-52-8$ \\
\end{tabular} & C. I. DISPERSE RED 1 & CI 11110 \\
\hline & C. I. DISPERSE BLUE 1 & $\mathrm{Cl} 64500$ \\
\hline & C. I. DISPERSE BLUE 7 & CI 62500 \\
\hline & C. I. DISPERSE BLUE 26 & Cl 63305 \\
\hline & C. I. DISPERSE BLUE 102 & \\
\hline & C. I. DISPERSE ORANGE 1 & Cl 11080 \\
\hline & C. I. DISPERSE ORANGE 76 & \\
\hline & C. I. DISPERSE RED 11 & Cl 62015 \\
\hline & C. I. DISPERSE RED 17 & Cl 11210 \\
\hline & C. I. DISPERSE YELLOW 1 & CI 10345 \\
\hline & C. I. DISPERSE YELLOW 9 & Cl 10375 \\
\hline & C. I. DISPERSE YELLOW 39 & \\
\hline & C. I. DISPERSE YELLOW 49 & \\
\hline
\end{tabular}

料を追加したものを認定基準として整理した．当該りス トは，ドイッにおいて日用品への使用が禁止されている 物質を含んでおり，エコマーク商品類型 No. 103 「再生 PET 樹脂を使用した衣服」などで採り上げたアゾ系染料 リスト（ドイツ日用品規制を参考に作成）を大幅に強化 したものである．認定基準は申込商品への使用禁止（処 方構成成分として添加していないこと）とした．証明方 法については紡績事業者などからの自己証明書のみとす るのではなく, 申込者の使用の有無に関する証明書に, 染料供給元事業者の証明書を添付することで出所を明ら
かにすることとした，反毛繊維などの利用促進を図る前 提があるため, 不純物としての混入などの可能性は否定 できないことから,含有試験の義務づけは行わなかった。

クロム系染料は, 現在約 $4700 \mathrm{t} の$ 生産量があり，主と して黒や紺色を出すために衣服などにも使用されてい る. 重金属削減の観点から, エコマーク商品類型 No. 103 「再生 PET 樹脂を使用した衣服」において羊毛以外の緎 維は使用のないこととされている. 今回あらためて見直 した結果, 羊毛業界において代替染料の開発を進めてい るものの, 現在においてもクロム系染料の使用は欠かせ ないものとなっており, 従来どおり, 羊毛以外の繊維は クロム系染料の使用のないこととした。

綿における塩素漂白については, 高付加価值商品とし て代替商品の製造・販売がすでに取り組まれており, 漂 白剤の使用を抑制するため，認定基準を策定する項目と して選定された．認定基準は，漂白工程を制限するもの ではなく，無漂白または過酸化水素漂白について特にそ の旨をマーク表示し, 環境保全型商品として消費者にア ピールしてゆくものとした.「無漂白」の定義は, 日本 オーガニックコットン協会の認証基準に準じ, 仕上加工 工程における薬剤を表 3 のとおり使用または使用禁止し た綿製品とした。なお，精練・漂白工程が同一工程のも のは, 過酸化水素による漂白が一般的であり, 特に環境 保全上の問題となる事項も挙げられなかったことから， 「過酸化水素漂白」として認めることとした。

羊毛の防縮加工は, 先加工として一部で塩素処理がな されている. 主な羊毛の防縮加工はポリウレタン樹脂に よる後加工であり, 羊毛における先加工としての塩素処 理については, 直接的な認定基準ではなく, 工場として 環境法規などを遵守することとし, 本項目は認定基準を 策定する項目として選定された。

蛍光増白加工剂, 難燃加工剂, 柔軟加工剂, 衛生加工 剤および製品漂白加工剮については, 経済産業省通達に 準じることとし，事業者が自主的に当該物質の使用量を 抑制することを期待した報告レベルの基準項目とした。 綿製品については，無漂白および過酸化水素漂白におけ る漂白剤の使用抑制とともに, 蛍光増白剂についても使 用のないこととした。

繊維製品は, 以上の他に分離 - 吸着機能加工, 力学的 - 形態学的加工, 親水 - 親油性加工, 熱特性加工, 電気 - 電子特性加工, 光特性加工, スキンケア加工などの多 様な加工があり, 様々な加工剂を使用している。本商品 類型の検討過程では, 候補となる加工剤のリスト作成が なされたものの, 認定基準として策定するための基礎的 な知見が不足しており，本見直し作業では一部の加工剤 を使用禁止レベルまたは報告レベルとして整理するに留 まった。 
表 3 仕上加工工程での使用可能薬剤 ·使用禁止薬剤一覧

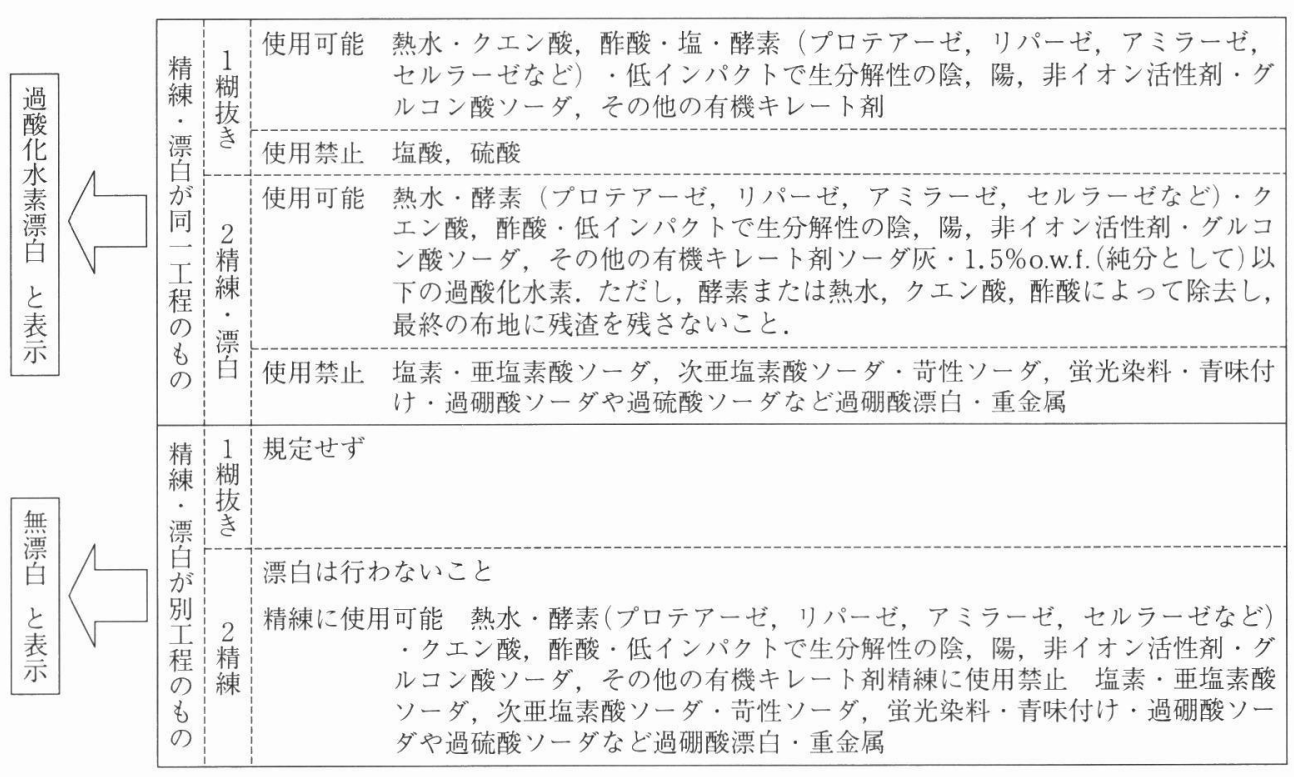

\section{おわりに}

当事業は1989年にスタートし，2003年 2 月で15年目を 迎える。多くの関係者および消費者の指導を受け，環境 に優しくありたいと願う消費者によるエコマーク認定商 品選択も飛躍的に進展していると考えている. 2001年に は「国等による環境物品等の調達の推進等に関する法律 (グリーン購入法)」が施行され, 環境保全型商品の市場 はますます広がっており，エコマークの役割も重要性を 増している。商品の環境情報を提供する動きも加速して おり，グリーン購入ネットワーク（GPN）の「えこどこ navi」やインターネットショッピングモールとしての機 能も有する「Green Stationエコマーク商品総合情報サ イト」をはじめ, 各事業者のサイトでも商品の環境情報 を入手することができるようになった。消費者がこうし た多くの情報の中から目当ての環境保全型商品を選択す る際には，マークの有無で判断可能なエコマークがひと つの目安となることも期待される。エコマーク事業に関 する情報は当協会のホームページ上で広く提供に努めて
おりＵRLは以下のとおりである。

http://www.jeas.or.jp/ecomark

環境に配慮した生活様式を普及していくためには, 消 費者, 行政, 産業界など関係各方面の幅広い支援と協力 が不可欠である。エコマークというひとつのラベルでは あるが, 環境保全の一層の進展のため, 今後も努力をし ていく所存である.

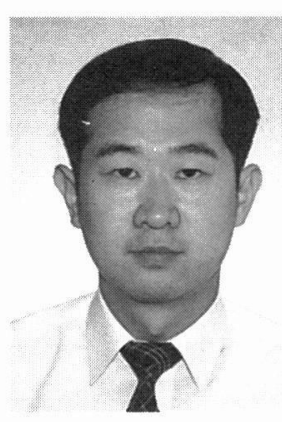

佐野 裕隆(さのひろたか)

平成 7 年, 明治大学農学部農学科 卒, 同年より(財)日本環境協会に勤務, エコマーク事業など環境保全型商品 普及促進を担当, 現在, 同事業にお いて繊維製品認定基準の策定も担 当, 環境教育事業としてこども環境 相談室を兼任, 主な発表論文に一般 工業化住宅への環境保全型商品の導 入に関する一考察がある。(財日本 環境協会, =105-0003 東京都港区 西新橋1-7-2, 虎の門高木ビル, TEL. 03-3508-2662, FAX. 03-3508 -2656 ) 